\title{
THE ROLE OF PSYCHOLOGICAL STRENGTHS, COPING STRATEGIES AND WELL-BEING IN THE PREDICTION OF ACADEMIC ENGAGEMENT AND BURNOUT IN FIRST-YEAR UNIVERSITY STUDENTS
}

\author{
EL PAPEL DE LAS FORTALEZAS \\ PSICOLÓGICAS, LAS ESTRATEGIAS DE \\ AFRONTAMIENTO Y EL BIENESTAR EN LA \\ PREDICCIÓN DEL ENGAGEMENT Y DEL \\ BURNOUT ACADÉMICO, EN ESTUDIANTES \\ UNIVERSITARIOS DE PRIMER CURSO
}

\author{
RICHARD MERHI $^{1}$, ÁNGELES SÁNCHEZ-ELVIRA-PANIAGUA ${ }^{1}$, \\ AND FRANCISCO JOSÉ PALACÍ ${ }^{1}$
}

Cómo referenciar este artículo/How to reference this article:

Merhi, R. Sánchez-Elvira-Paniagua, A., \& Palací, F. J. (2018). The Role of Psychological Strengths, Coping Strategies and Well-Being in the Prediction of Academic Engagement and Burnout in First-Year University Students [El papel de las fortalezas psicológicas, las estrategias de Afrontamiento y el bienestar en la predicción del engagement y del burnout académico, en estudiantes universitarios de primer curso]. Acción Psicológica, 15(2), 51-68. https://doi.org/10.5944/ap.15.2.21831

\begin{abstract}
Two of the most significant challenges that higher education institutions are currently addressing is the
\end{abstract}

prevention of students' failure and drop-out, and the promotion of students' retention, success, and wellbeing. Within the framework of the demands-resources model, the present study explored the role that different variables play in predicting academic engagement and burnout, two

Correspondence address: Richard Merhi. Universidad Nacional de Educación a Distancia (UNED), España.

Email: ohni2003@gmail.com

ORCID: Richard Merhi (http://orcid.org/0000-0003-2379-2218), Ángeles Sánchez-Elvira Paniagua (http://orcid.org/00000002-3007-3935) y Francisco José Palací Descals (http://orcid.org/0000-0002-2585-6476).

${ }^{1}$ Universidad Nacional de Educación a Distancia (UNED), España.

Retrieved: May 6, 2018.

Aceptado: July 26, 2018. 
relevant and distinct characteristics that have been previously related to students' well-being and academic performance. We applied a multivariate approach with this aim in mind to analyse the contribution of relevant psychological strengths in academic environments (resilience, personal initiative, and academic motivation), the perception of academic demands, procrastination and different coping strategies when approaching studies (persistence, avoidance and anxiety), student's affect and academic satisfaction. The contribution of the efficacy subscale of academic burnout as an independent personal resource and the consideration of the so-called core burnout were also assessed. A sample of 173 first-year students of 20 face-to-face teaching universities participated in this study. The results showed, on the one hand, the positive nature of academic engagement, predicted by personal resources, characterised by intrinsic motivation and efficacy, as well as academic persistence, high levels of well-being and academic satisfaction. On the other hand, the predictors of academic burnout were mainly the perception of academic demands, procrastination, and negative affect, besides, in a negative sense, low levels of engagement and intrinsic motivation. Likewise, core burnout showed the same pattern of predictors as burnout, except for engagement and intrinsic motivation.

Keywords: Academic burnout; Academic engagement; Psychological strengths; Academic demands; Firstyear students; Student's well-being.

\section{Introduction}

Preventing dropouts and promoting not only student retention but also academic success is an essential objective shared by international organisations and governments, researchers and universities (Michavila et al., 2012; Tinto, 2012). In this sense, the first year at the university seems to represent the most critical period for student retention. Although this moment of the transition to a different stage of life may involve positive changes and emotions, it may also increase the levels of uncertainty, anxiety and academic stress (Casuso, 2011; White, Slemp, $\&$ Murray, 2017), due to the necessary adaptation for a new and unfamiliar environment that presents different demands and responsibilities and requires putting many personal resources into play (Tinto, 2012). Research on student dropout and failure in higher education (HE) consistently reveal that most cases occur during the first two academic years (Crue Universidades Españolas, 2018; European Commission, 2015). An extensive body of research on this problem has been conducted in the fields of education and psychology.

Increasing attention is being placed on students' wellbeing as the main objective of HE institutions (Harvard, 2016). Positive psychology, oriented toward optimal human functioning, personal development, and welfare, contributes to this issue by focusing on the main role of human strengths and resources (Seligman \& Csikszentmihalyi, 2001). According to its postulates, positive education entails incorporating students' well-being as a priority objective in education (Salanova \& Llorens, 2016; Seligman \& Adler, 2018). Therefore, it will be necessary to investigate which variables and conditions promote and enhance, not only students' performance but also their well-being and which pose a threat. It is also essential to pay particular attention to the interaction of personal strengths and resources with academic demands, and their impact in significant areas, such as academic success and failure (Williams, Horrell, Edmiston, \& Brady, 2018), and psychological welfare (Harvard, 2016).

\section{The Demands-Resources (D-R) Model applied to the Educational Field}

The demands-resources model (Bakker \& Demerouti, 2013; Schaufeli \& De Witte, 2017), mostly applied in job settings (Schaufeli \& Taris, 2014), could be a useful framework for addressing the research on personal resources that may help students to cope with their academic demands successfully increasing their wellbeing. The model assumes that environmental characteristics can be divided into two categories: resources (capacities of each to face tasks in a specific context) and demands (aspects of a specific context that require significant physical, cognitive and/or emotional effort) (Schaufeli \& Taris, 2014). Accumulating evidence shows that an increase in (job and academic) resources correlates with an increase in wellbeing, whereas their loss -or the risk of their loss- may 
cause their decrease (Halbesleben, 2010; Mäkikangas, 2016; Schaufeli \& De Witte, 2017). Resources also cushion the negative effect, per se, of demands; consequently, we could assume that the greater the resources, the higher the likelihood of addressing the demands, to where they may even be considered as challenges to overcome. A proper balance of resources to face demands will represent better levels of work, academic and psychological outcomes.

In academic environments, personal resources (e.g., intrinsic motivation, efficacy perception, etc.) would then relate to how students face demands (e.g., workload) and represent a source of well-being and success themselves (Carmona-Halty, Salanova, Llorens, \& Schaufeli, 2018). Even though the number of studies focused on students' resources and personal strengths that lead them to face their academic demands successfully is increasing (e.g., Salanova, Martínez, Bresó, Llorens, \& Grau, 2005; Schaufeli \& Taris, 2014), according to White et al. (2017) the D-R model has been scarcely applied to university students (e.g., Barr, Sessa, Summer, \& Bragger, 2015; Mokgele \& Rothman, 2014). Nevertheless, D-R postulates could be well-suited to this field (Schaufeli \& Taris, 2014). Likewise, work contexts, performance in academic settings also requires the use of individuals' resources to overcome those demands with which students must cope, such as tests/evaluations, deadlines, relationships with colleagues and supervisors, and so on (Mokgele \& Rothman, 2014).

In line with these postulates, it is crucial to determine which personal strengths and resources should be mainly considered in academic settings to enhance students' wellbeing and success. Conversely, more research is needed to establish which characteristics could increase students' perception of demands that boost discomfort and the risk of dropping out.

The present study is centred in two main psychological characteristics that have proven to present strong evidence of their positive vs negative impact on individuals' performance and well-being, both in work and academic settings: engagement and burnout, respectively (Leiter \& Maslach, 2017; Taris, Ybema, \& Van Beek, 2017). Accordingly to the D-R model, we aimed to identify those personal resources, demands and learning coping processes that lead to developing academic engagement and burnout in first-year university students.

\section{Psychological Resources and their Relationships with Academic Engage- ment}

Engagement has been widely addressed and conceptualised in the literature (e.g., Halbesleben, 2010; Leiter \& Maslach, 2017; Martínez \& Salanova, 2003). A common and shared conceptualization among positive psychologists defines engagement as a persistent positive psychological state over time composed of vigour, corresponding to high levels of mental energy and persistence in the face of obstacles; dedication or enthusiasm towards the task or set of relevant tasks performed; and absorption, or ability to concentrate deeply, with a feeling that time "flies by" (Salanova, Bresó \& Schaufeli, 2005). In education, results repeatedly confirm the positive impact of academic engagement on student retention (Garbanzo, 2007), wellbeing (Carmona et al., 2018) and academic performance (Michavila et al., 2012), identified as the most important characteristics for preventing student failure and dropout (Tinto, 2012).

Academic engagement has been previously related to different motivational, cognitive and emotional psychological resources. Considered, primarily, as a positive motivational construct (Schaufeli, Salanova, GonzálezRomá, \& Bakker, 2002), engaged students are highly intrinsically motivated (Ryan \& Deci, 2000). That would explain their high persistence in the face of difficulties (Salanova, Martínez et al., 2005; Tinto, 2012), their greater academic satisfaction and, even, their better academic performance (Garbanzo, 2007).

Engagement has also been linked to other personal resources that have proven relevant in the domains of organisations and academia, such as personal initiative (Frese \& Fray, 2001), a behavioural pattern characterised by the self-initiated, proactive and persistent performance that is objectives-driven and action-oriented. Significant positive relationships with students' performance and psychological well-being have also been found in students 
with high levels of personal initiative (Lisbona, Palací, Salanova, \& Frese, 2018).

Another important resource related to students' engagement levels is the perception of efficacy (Tinto, 2012), defined as the degree of preparation that the person self-evaluates as possessing in a specific field (Bandura, 2001). Thus, students who perceive themselves to be more efficacious attribute their failures to a lack of effort, rather than to insufficient capacity, are more likely to initiate study behaviours due to a higher expectation of success, and are prone to set more self-improvement goals requiring more persistence and determination, raising their academic motivation and subsequently, their engagement (Pérez et al., 2018; Salanova, Martínez et al., 2005). Consequently, the self-perception of efficacy could be a positive and necessary precursor for engagement. From a longitudinal perspective, Salanova, Bresó, and Schaufeli (2005) propose a positive spiral through which the perception of efficacy and engagement wield a positive, reciprocal and continuous influence.

Engagement and resilience have also been related (Martínez, Peñalver, \& Meneghel, 2016). Given the inherent difficulties and challenges that characterise university life, resilience, defined as the ability to recover and cope with adversity with a more positive perception of problems and difficulties (You, 2016), can be valued as a significant personal strength. Furthermore, resilient students present higher levels of intrinsic motivation (Martínez et al., 2016), well-being (Grant \& Kinman, 2012), academic performance (Martin \& Marsh, 2006) and retention (European Commission, 2015).

Also, engaged students seem to make use of more proactive coping strategies (e.g., Grant \& Kinman, 2012; Sánchez-Elvira-Paniagua, Fernández, \& Amor, 2006). In this sense, good management of demands and challenges has been related to these active coping strategies, such as persistence, by mediating those demands that impact on variables such as academic performance (O'Connor, Nguyen, \& Anglim, 2016; Salmela-Aro \& Read, 2017). To the contrary, academic engagement has a negative association with academic procrastination (González-Brignardello \& Sánchez-Elvira-Paniagua, 2013). Academic procrastination is defined as the tendency to intentionally delay the start, execution and completion of academic tasks and duties "despite expecting to be worse off for the delay" (Steel \& Klingsieck, 2016, p. 37).

\section{Demands in Academic Settings and their Relationship with Academic Burnout}

Academic burnout is defined as a persistent negative mental state regarding studies, mainly characterised by emotional exhaustion accompanied by discomfort, cynicism or detachment from studies and lack of academic self-efficacy in students without psychological disorders (Llorens, García-Renedo, \& Salanova, 2005; Maslach \& Leiter, 1997).

The experience of academic burnout has been consistently linked to the greater perception of academic demands (Mokgele \& Rothman, 2014) and academic stress (Casuso, 2011), and usually interpreted as a consequence (García-Ros, Pérez-González, Pérez-Blasco, \& Natividad, 2012). Situations such as university transition, academic overload, lack of time, social relations and performance on academic tests may be considered as academic demands, which are likely to generate stress if students perceive that they lack proper resources and/or strategies to face them (Casuso, 2011; García-Ros et al., 2012; White et al., 2017). According to the transactional model of Lazarus and Folkman (1987) and the D-R model (Bakker \& Demerouti, 2013), people will perceive stress and, eventually, burnout, when they consider that the demands exceed their resources or capacities. Burnout not only entails distress but also impaired academic performance (Schaufeli, Martínez, Marqués-Pinto, Salanova, \& Bakker, 2002) and a greater tendency toward dropping out, as well (Martínez \& Marques, 2005).

Furthermore, academic burnout has been associated with fewer resources (Schaufeli \& Taris, 2014) and harmful learning strategies such as procrastination (GonzálezBrignardello \& Sánchez-Elvira-Paniagua, 2013), which has been inversely related to self-regulatory processes, self-efficacy, subjective well-being and academic performance (Kim \& Seo, 2015; Klaassen, Krawchuk, \& Rajani, 2008; Steel, 2007; Steel \& Klingsieck, 2016). 
Remembering what has been exposed before, we could postulate that academic engagement would be facilitated by a set of positive motivational, emotional and cognitive, personal resources that contribute toward perceiving fewer demands in the environment and a greater capacity for facing them properly. The outcome would be a positive impact on students' well-being and performance that would consolidate the resources and, eventually, result in greater engagement. On the contrary, academic burnout could be induced by a higher perception of demands and insufficient resources for coping with them, and poorer coping strategies for dealing with the demands properly, deleteriously affecting students' performance and wellbeing.

The previous relationships discovered between engagement and burnout with relevant personal resources and perceived demands guided the selection of the variables investigated in the present study.

\section{Academic Engagement and Burnout: Opposite poles?}

Engagement and burnout have been postulated as two states that show different and, in many cases, opposite relationships with different psychological variables inherent to academic performance. As seen before, previous evidence highlights that engagement relates more to personal resources and burnout to the perception of existent demands and stress (Taris et al., 2017).

However, some discrepancies currently exist regarding the conceptualisation and measurement of engagement and burnout (e.g., Schaufeli \& De Witte, 2017; Taris et al., 2017). Although some researchers argue that they represent opposite extremes of the same construct (e.g., Maricotui, Sulea, \& Lancu, 2017), others point out that research is not unequivocally conclusive in this regard (e.g., Schaufeli \& De Witte, 2017).

Whereas there is evidence of a clear antagonism of the dimensions that comprise the so-called "core" of engagement and burnout: vigour vs exhaustion and dedication vs cynicism (Schaufeli \& Salanova, 2007), nevertheless, the perception of lack of efficacy as a component of burnout poses another controversy among researchers. It has been postulated, first, that the measurement of burnout using a subscale with reversed-positive items of efficacy may not reliably assess this characteristic (Schaufeli \& Salanova, 2007); and, second, that it could be a necessary precursor, more so rather than a real component, of burnout (Salanova et al., 2004). Also, the perception of efficacy could precede engagement levels, acting as a resource and a possible mechanism for self-motivation, in those who perceive themselves as capable of facing a task often put more of their resources into action, are more persistent and set further-reaching goals (Salanova et al., 2004). In that case, it would be interesting to explore the contribution of the perception of efficacy in developing engagement and burnout alike.

\section{Objectives}

Based on the previous evidence and within the framework of the demands-resources model, the main objective of the present study was to explore, under a multivariate approach, the contribution of a set of relevant personal resources, academic demands, learning and coping strategies, affect and satisfaction in the prediction of students' engagement and burnout in their first university year, before their first exams. Another objective was to look for the likely contribution of efficacy as an independent psychological resource.

Personal resources were expected to predict engagement, whereas burnout, and core burnout specifically, was expected to be mostly predicted by the perception of more academic demands.

\section{Method}

\section{Sample}

One hundred and seventy-three incoming first-year students from 20 Spanish face-to-face (traditional learning) universities ( $68.8 \%$ female), mostly enrolled in Social and Legal Sciences, volunteered to participate in this study. The mean age was 22.99 years old (ranging from 18 to 58 years, $\mathrm{SD}=7.62$; see Table 1 ). This average 
age was high due to some extreme values; nevertheless, $71.7 \%$ of our sample was between 17 and 21 years old.

Table 1.

Sample description.

\begin{tabular}{lc}
\hline Male & $31.2 \%$ \\
Female & $68.8 \%$ \\
\hline Arts \& Humanities & $9.8 \%$ \\
Social and Legal Sciences & $59.0 \%$ \\
Engineering and architecture & $19.1 \%$ \\
Health Sciences & $5.2 \%$ \\
Sciences & $6.9 \%$ \\
\hline From 17 to 21 years-old & $71.7 \%$ \\
From 22 to 25 years-old & $12.1 \%$ \\
$\mathbf{2 6}$ or more years-old & $16.2 \%$ \\
\hline $\mathbf{N}$ & $\mathbf{1 7 3}$ \\
\hline
\end{tabular}

\section{Instruments}

A Spanish online battery of tests was designed to be voluntarily completed. The battery included socio-demographic, academic and psychological variables, as described below. Internal reliability found in previous studies was adequate (García-Ros et al., 2012; NotarioPacheco et al., 2011; Salanova, Bresó, \& Schaufeli, 2005; Salanova, Schaufeli, Llorens, Peiró, \& Grau, 2000; Sandín et al., 1999).

Socio-demographic variables. Ad-hoc items were used to collect information about students' age, gender, university, the branch of knowledge, current academic year and total number of ECTS (European Credit Transfer System) in which they were enrolled.

Academic engagement. Engagement was measured with the student version of the Utrecht Work Engagement Scale, UWES (Salanova et al. 2000). It is comprised of 15 items and a Likert-type scale ranging from 0 (never) to 6 (always). It consists of three dimensions: vigour (e.g. "when I study, I feel like I am bursting with energy"), dedication (e.g., "I am proud of my studies") and absorption (e.g., "I am immersed in my studies"). The global reliability coefficient in our study was .92 and $.83, .84, .84$ for absorption, dedication \& vigour subscales, respectively.
Academic burnout. Burnout was measured with the Maslach Burnout Inventory-Student Survey, MBI-SS (Schaufeli, Salanova et al., 2002) in its Spanish adaptation (Salanova, Martínez et al., 2005). It is comprised of 15 items grouped into three dimensions: exhaustion (e.g., "I feel used up at the end of a day at university"), cynicism (e.g., "I doubt the significance of my studies") and efficacy (e.g., "During class I feel confident that I am effective in getting things done") (reverse positive items). The MBI-SS uses a Likert-type scale ranging from 0 (never) to 6 (always). The global reliability coefficient was .86 and $84, .86, .84$ for exhaustion, cynicism and efficacy subscales, respectively. Core burnout, comprising the dimensions of exhaustion and cynicism, showed a .83 reliability coefficient.

\section{Psychological resources}

Reasons for degree selection. Students were asked about the reasons why they chose their current studies, through 14 items, and a Likert-type scale ranging from 1 (not important at all) to 4 (very important). Items were grouped into two subscales: intrinsic ("for personal satisfaction") and extrinsic ("it is a way to increase the chances of getting a promotion") motives. The reliability coefficients were .86 for intrinsic motives and .71 for extrinsic ones.

Academic motivation. Intrinsic and extrinsic motivation subscales (Batería de Escalas de Aprendizaje Autorregulado, Sánchez-Elvira-Paniagua et al., 2006). It consists of a 13-item Likert-type scale ranging from 1 (not at all) to 4 (almost always). "I put a lot of effort into my studies" or "the fear of not fulfilling my studies is what motivates me the most" represent examples of two items. The reliability coefficients were .73 for identified intrinsic motivation, .55 for pure intrinsic motivation, and .74 for extrinsic motivation.

Personal initiative. Measured with the Self-reported Initiative Scale (Frese, Fay, Hilburger, Leng, \& Tag, 1997) in its Spanish adaptation (Las-Hayas, Lisbona, \& Palací, 2018). It is comprised of seven items (e.g., "I solve problems without waiting to see what's next") and a Likert-type scale ranging from 1 (strongly disagree) to 4 (strongly agree). The scale reliability coefficient was .81 . 
Resilience. Connor-Davidson Resilience Scale (Connor \& Davidson, 2003), in its Spanish adaptation (Notario-Pacheco et al., 2011). It is comprised of 10 items and a Likert-type scale ranging from 0 (not at all) to 4 (almost always). One example of an item is "I believe that I am a strong person when I face the challenges and vital difficulties". The scale reliability coefficient was .89 .

\section{Learning and Coping Strategies}

Academic procrastination. The Academic Procrastination questionnaire (González-Brignardello \& SánchezElvira-Paniagua, 2013) is comprised of 18 items (e.g., "I work in a non-systematic way (disorderly)" and a Likerttype scale ranging from 1 (absolutely not) to 5 (totally). The scale reliability coefficient was .90 .

Coping strategies. Measured with the Batería de Escalas de Aprendizaje Autorregulado (Sánchez-Elvira-Paniagua et al., 2006). Due to the objectives of this study, three of their subscales were selected, comprised of 19 items: persistence (e.g., "I strive for studying subjects, whether I like them or not"), avoidance strategies in the face of difficulties (e.g., "I usually throw in the towel facing significant difficulties when studying") and academic anxiety (e.g., "I feel nervous while I'm studying"). The reliability coefficients for each subscale were $.83, .88$ and .60 , respectively.

\section{Academic Demands}

They were measured with the Cuestionario de Estrés Académico en la Universidad (University Academic Stress Questionnaire; García-Ros et al., 2012). According to the objectives of this study, only two subscales were selected, comprised of 13 items and a Likert-type scale ranging from 1 (no stress) to 6 (much stress): academic obligations (e.g., "doing exams") and academic records and future perspectives (e.g., "to obtain high grades in the subjects"). The reliability coefficients were .81 for academic obligations and .79 for academic records and future perspectives.

\section{Satisfaction and Affect}

Affect. The Positive and Negative Affect Schedule (Watson \& Clark, 1988) in its Spanish adaptation (Sandín et al., 1999). It is comprised of 20 items grouped into two subscales, positive and negative affect. Students were asked about how intensely they experienced last week each of 20 feelings (e.g., enthusiastic, ashamed) with a Likert-type scale ranging from 1 (very slightly) to 4 (extremely). The reliability coefficients were .88 for positive affect and .91 for negative affect. Likewise, the affect balance measure (positive affect - negative affect) was calculated.

Degree of satisfaction with the studies. It was measured with a single ad-hoc item ("indicate the satisfaction level with your studies") and a Likert-type scale ranging from 1 (none) to 5 (very much).

\section{Procedure}

The faculty of the participating universities distributed the link to the battery of online questionnaires. The test was administered prior to the first semester evaluation period, between November and December. The Qualtrics $(\mathbb{C}$ software used allowed for responding to the instruments using a computer, tablet or phone, and included explicit, informed consent.

\section{Statistical Analyses}

Pearson correlation coefficients were conducted to analyse the relationships of academic engagement and burnout with the rest of the variables of the study. Subsequently, to determine what variables predicted the levels of engagement and burnout, two multiple regression analyses, method forward, were carried out. Those variables with a correlation with the criterion ones equal to or higher than .35 were introduced in the model as predictor variables. All statistical analyses were performed with the SPSS 24 software. 
Table 2.

Descriptive analyses and correlations between engagement and burnout, core burnout and their subscales.

\begin{tabular}{|c|c|c|c|c|c|c|c|c|c|c|}
\hline & $M(S D)$ & (1) & (2) & (3) & (4) & (5) & (6) & (7) & (8) & (9) \\
\hline Engagement (1) & $4.69(1.00)$ & - & $-.53^{* *}$ & $-.33^{\star \star}$ & $.88^{* *}$ & $.82^{\star \star}$ & $.91^{* *}$ & -.10 & $-.55^{\star \star}$ & $.63^{\star *}$ \\
\hline Burnout (2) & $3.10(.90)$ & & - & $.91^{\star *}$ & $-.35^{* *}$ & $-.49^{\star *}$ & $-.55^{\star *}$ & $.70^{\star *}$ & $.77^{* *}$ & $-.71^{\star *}$ \\
\hline Core burnout (3) & $3.03(1.05)$ & & & - & $-.20^{* *}$ & $-.32^{\star *}$ & $-.34^{* *}$ & $.86^{\star *}$ & $.72^{\star *}$ & $-.36^{* *}$ \\
\hline Absorption (4) & $4.31(1.18)$ & & & & - & $.56^{\star *}$ & $.72^{\star *}$ & -.03 & $-.40^{* *}$ & $.45^{\star *}$ \\
\hline Dedication (5) & $5.58(1.04)$ & & & & & - & $.63^{* *}$ & -.04 & $-.62^{* *}$ & $.54^{* *}$ \\
\hline Vigour (6) & $4.19(1.23)$ & & & & & & - & $-.17^{*}$ & $-.45^{\star *}$ & $.65^{* *}$ \\
\hline Exhaustion (7) & $3.80(1.31)$ & & & & & & & - & $.28^{* *}$ & -.13 \\
\hline Cynicism (8) & $2.16(1.18)$ & & & & & & & & - & $-.50^{* *}$ \\
\hline Efficacy a $(9)$ & $3.22(1.12)$ & & & & & & & & & - \\
\hline
\end{tabular}

\section{Results}

\section{Correlational Analyses}

Correlational analyses between engagement, burnout and core burnout scales and its subscales were carried out.

Engagement and burnout were significantly and negatively correlated (-.53), though that correlation did not allow us to conclude that the constructs were opposite. Also, the correlation between engagement and core burnout were substantially smaller (-.33). That was because efficacy correlated higher with engagement (.63) than with core burnout (-.36). The efficacy subscale (measured in its original, positively-worded items) presented significant correlations with both global measures and its subscales, except exhaustion (-.13); additionally, positive and significant correlations with vigour, dedication and absorption were found, and negative correlations with cynicism. The strongest correlation was with vigour (.65) (Table 2). Given that efficacy correlated with engagement subscales more than with the burnout ones (except for absorption) and given the theoretical background previously explained, the efficacy subscale (here considered as the belief in ones'abilities and skills to cope and deal satisfactorily with study demands) was hereafter considered an independent personal resource and a predictor variable instead of a burnout subscale, for this study.

Table 3 shows the correlations obtained between the global scales of engagement, burnout and core burnout and the set of variables studied. Engagement showed moderate to high positive and significant correlations with all the personal resources, except extrinsic motivations, with the correlations with pure intrinsic motivation (.69) and efficacy (.63) being the highest. These correlations were also significant, but inverse, with burnout, although their value was significantly reduced when core burnout was considered, with low effect sizes.

Regarding the ways students coped with their studies, our results revealed that the higher the engagement, the greater the persistence and lower the procrastination, avoidance and anxiety. On the contrary, the higher the burnout, the higher levels of procrastination, avoidance and anxiety when facing academic tasks and the less persistence. These correlations decreased to some extent when core burnout was considered, except for academic anxiety, which experienced a slight increase.

Engagement did not show significant correlations with the perception of academic demands, unlike burnout, which showed positive and significant correlations, and core burnout, which showed even higher correlations.

Finally, engagement was positively correlated with positive affect but not with negative affect, in a different way to burnout, which correlated significantly both with negative affect and inversely with positive affect, and core burnout, which presented an even increased correlation with negative affect. Due to this pattern, burnout and core burnout alike presented significant, inverse correlations with a positive balance of affect. 
Table 3.

Descriptive analyses and correlations between engagement and burnout, core burnout and their subscales.

\begin{tabular}{|c|c|c|c|c|}
\hline & $M(S D)$ & Engagement & Burnout & Core burnout \\
\hline \multicolumn{5}{|l|}{ Reasons for degree selection } \\
\hline Intrinsic motivations & $3.28(.63)$ & $.49^{\star *}$ & $-.37^{* *}$ & $-.26^{\star *}$ \\
\hline Extrinsic motivations & $2.26(.65)$ & .12 & .02 & .08 \\
\hline \multicolumn{5}{|l|}{ Personal resources } \\
\hline Personal initiative & $3.37(.71)$ & $.57^{* *}$ & $-.41^{* *}$ & $-.16^{*}$ \\
\hline Pure intrinsic motivation & $2.7(.64)$ & $.69^{* *}$ & $-.48^{* *}$ & $-.30^{* *}$ \\
\hline Identified intrinsic motivation & $3.71(.37)$ & $.59^{* *}$ & $-.42^{* *}$ & $-.28^{* *}$ \\
\hline Extrinsic motivation & $2.79(.72)$ & $.24^{* *}$ & .09 & $.22^{* *}$ \\
\hline Resilience & $3.67(.82)$ & $.45^{\star *}$ & $-.37^{* *}$ & $-.25^{\star *}$ \\
\hline Efficacy & $3.22(1.12)$ & $.63^{* *}$ & & $-.36^{* *}$ \\
\hline \multicolumn{5}{|c|}{ Learning and coping Strategies } \\
\hline Academic procrastination & $3.05(.85)$ & $-.41^{* *}$ & $.52^{\star *}$ & $.40^{\star *}$ \\
\hline Persistence & $3.12(.54)$ & $.64^{* *}$ & $-.38^{* *}$ & $-.23^{* *}$ \\
\hline Anxiety & $1.50(.49)$ & -.08 & $.49^{\star *}$ & $.52^{* *}$ \\
\hline Avoidance & $2.45(.76)$ & $-.39^{* *}$ & $.45^{\star *}$ & $.34^{* *}$ \\
\hline \multicolumn{5}{|l|}{ Academic demands } \\
\hline Academic obligations & $3.52(.78)$ & -.02 & $.50^{\star *}$ & $.54^{* *}$ \\
\hline Future perspectives & $3.02(.96)$ & -.02 & $.39^{* *}$ & $.51^{\star *}$ \\
\hline Enrolled ECTS & $56.06(17.25)$ & -.04 & .03 & .11 \\
\hline \multicolumn{5}{|l|}{ Satisfaction and Affect } \\
\hline Degree Satisfaction & $3.95(.82)$ & $.54^{* *}$ & $-.50^{* *}$ & $-.42^{* *}$ \\
\hline Positive affect & $2.54(.62)$ & $.53^{\star *}$ & $-.49^{\star *}$ & $-.38^{* *}$ \\
\hline Negative affect & $2.09(.76)$ & -.06 & $.45^{\star *}$ & $.51^{* *}$ \\
\hline Affect balance & $.45(1.14)$ & $.32^{* *}$ & $-.57^{\star *}$ & $-.54^{* *}$ \\
\hline
\end{tabular}

Note. ${ }^{* *} p<.01$ (bilateral), ${ }^{*} p<.05$ (bilateral).

Given the correlations obtained, we can conclude that in general engagement and burnout demonstrated a pattern of inverse relations with personal resources and coping strategies, academic demands, affect and satisfaction levels. Besides, core burnout presented stronger relationships with academic demands and negative affect than with burnout. Finally, it should be noted that engagement and both burnout measures did not correlate with the number of enrolled ECTS.

\section{Predictive Analyses of Engagement, Burnout, and Core Burnout}

Three multiple regression analyses, method forward, were carried out using engagement, burnout and core burnout levels as criterion variables (considering the positive-worded efficacy scale as an independent variable). Those variables with a correlation with the criterion ones equal to or higher than .35 were introduced as pre- dictor variables in each model. All variable scores were standardised (Table 4).

Seven predictors explained $68 \%$ of the variance of engagement. These predictors were, fundamentally, intrinsic motivational factors, concerning both the reasons for choosing the degree and the levels of academic motivation. A perception of efficacy, the use of persistence as an active coping strategy, positive affect and satisfaction with studies also contributed to engagement prediction. Therefore, a pattern associated with personal resources and active coping, with beneficial consequences for students, was found in the prediction of engagement levels.

Six predictors explained $63 \%$ of the variance of burnout. On the one hand, the experience of burnout was positively predicted by the perception of academic obligations, academic procrastination and negative affect; and on the 
Table 4.

Multiple regression analyses for the prediction of engagement and core burnout.

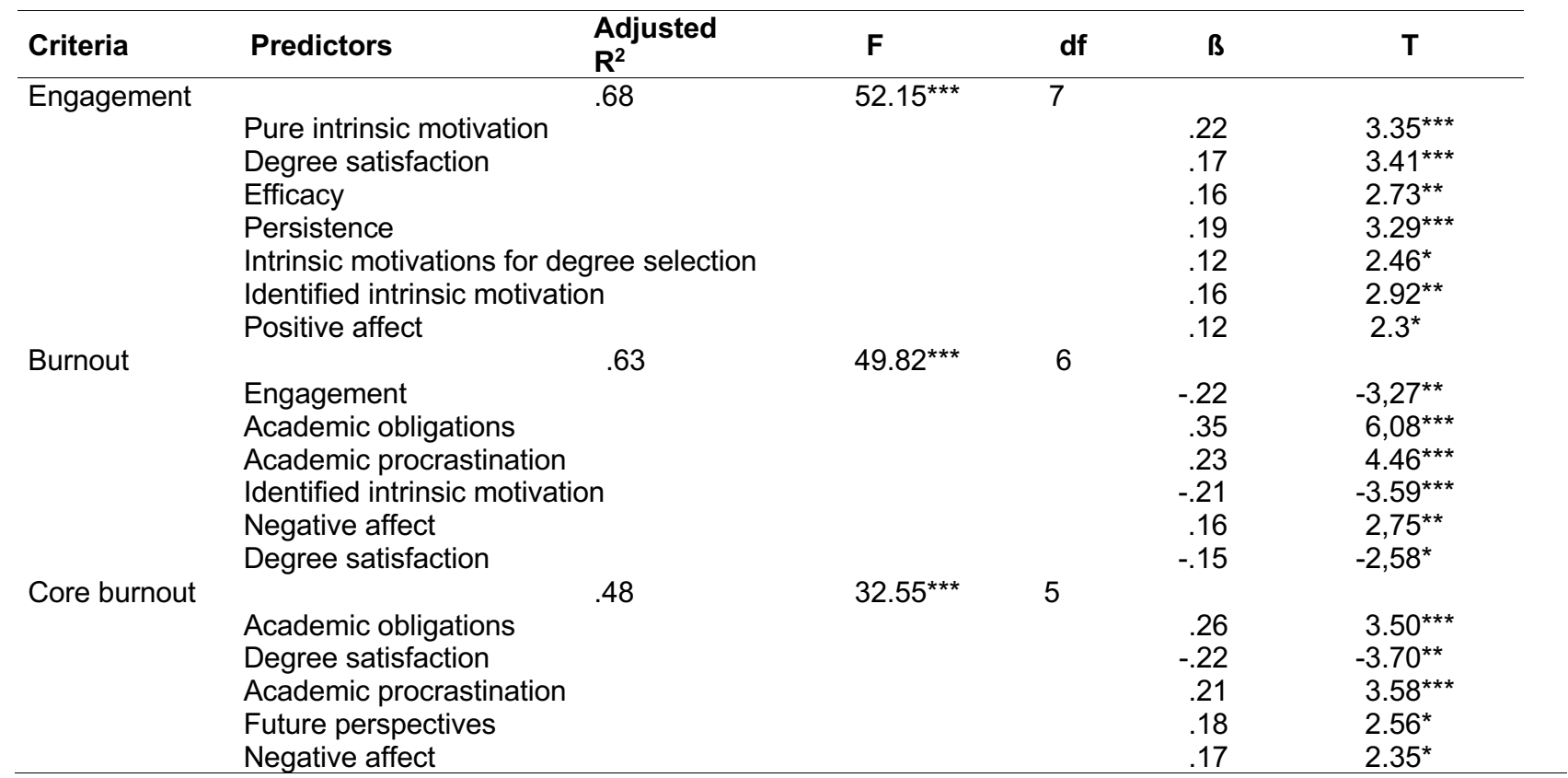

Note. ${ }^{*} p<.05,{ }^{* *} p<.01,{ }^{* * *} p<.001$.

other hand, negatively by engagement, identified intrinsic motivation and degree satisfaction. Accordingly, a pattern associated with academic stress and poor learning strategies, and also disengagement, dissatisfaction and demotivation, predicted burnout levels significantly. When core burnout was considered, the percentage of variance explained decreased to $48 \%$. Main predictors were also the experience of academic demands, negative affect, procrastination and dissatisfaction with studies. Therefore, core burnout was predicted by the perception of demands but not by the lack of personal resources, according to previous studies and hypotheses.

\section{Discussion}

The present study aimed to explore, in depth, the role of some relevant psychological characteristics in predicting the levels of engagement and burnout experienced by first-year students of face-to-face teaching universities before their first semester exams, using a multivariate demands-resources approach. For this purpose, relevant variables previously related to engagement and burnout, and supported by empirical evidence of their impact on well-being and academic performance, were considered (psychological resources, academic coping strategies, academic demands, affective states and academic satisfaction).

Our data demonstrated by using a multivariate approach that the engagement levels of first-year university students were strongly predicted by a set of relevant personal resources, mainly driven by intrinsic motivations and efficacy. The predictive value of having chosen a degree for intrinsic reasons is worth highlighting. In previous studies, this motivation was related to academic performance and dropout prevention (e.g., Vizoso \& AriasGundín, 2016). Also, persistence (as a proactive way of coping with studies), positive affect and academic 
satisfaction were significant predictors of the levels of engagement experienced by students before their first exams.

To the contrary, academic burnout was mainly predicted by the perception of academic demands and procrastination, and inversely by engagement (a motivational construct per se; Schaufeli, Martínez et al., 2002), and intrinsic motivation; finally, dissatisfaction with studies and negative emotions were significant predictors, as well, of the burnout experienced by students. Low levels of engagement (explained by a set of relevant personal resources as previously mentioned), would highlight the significant link between academic burnout and lack of resources, in line with other studies (e.g., Schaufeli \& Taris, 2014).

These analyses are also congruent with the demandsresources model, in which resources are related to greater well-being and, conversely, demands show a direct link to dissatisfaction (e.g., Bakker \& Demerouti, 2013; Mäkikangas, 2016).

Additionally, academic core burnout revealed similarities and differences with global burnout, although burnout was predicted by a greater percentage of the variance. Both constructs were mainly predicted by the perception of academic demands and procrastination, and also by dissatisfaction and negative affect. Nevertheless, engagement and identified intrinsic motivation did not predict core burnout levels when efficacy was considered an independent personal predictor, congruently with its strong relationship with these personal variables. These results are similar to those reported in previous studies (Bedewy \& Gabriel, 2015; García-Ros et al., 2012; Schaufeli \& Salanova, 2007; Salanova et al., 2004). Nonetheless, only $48 \%$ of core burnout variance could be explained in our study. Therefore further studies would have to gain a better understanding of this construct and its predictors.

In summary, our multiple regression analyses confirmed the hypotheses that different variables predict engagement and burnout, mainly the perception of personal resources (e.g., Barr et al., 2015) or academic demands (e.g., Mokgele \& Rothman, 2014), respectively.
Likewise, the study contributes to the current debate (Taris et al., 2017) as to whether engagement and burnout are two poles of the same construct. Moreover, to whether efficacy beliefs, as measured by the burnout scale, should be better considered a triggering factor in developing engagement and burnout, instead of a real component of the latter (e.g., Maricotui et al., 2017; Schaufeli \& De Witte, 2017).

First, our results indicate, in coherence with previous studies (e.g., Goering Shimazu, Zhou, Wadac, \& Sakai, 2017; Leiter \& Maslach, 2017), that although engagement and burnout were inversely related, they were not strictly antagonistic. Likewise, low scores in one dimension do not necessarily imply high scores in the other (Schaufeli \& De Witte, 2017).

Second, our results revealed that although the positively worded efficacy scale was significantly and inversely related to the so-called core burnout, it was even more strongly and positively related to engagement (global scale and subscales). These results are congruent with Schaufeli \& Salanova (2007), who caution when assuming that a reversed efficacy scale is a reliable assessment tool of the perception of inefficiency that characterises burnout. As these authors claim, efficacy and inefficacy beliefs should not be considered opposite constructs, and suggest that the former could be an element of engagement and the latter of burnout; in this case, different assessment instruments would be required. In parallel, according to the discussion raised by several authors as to whether efficacy actually represents a component of burnout or is instead a necessary precursor (e.g., Taris et al., 2017), several authors have postulated, on the one hand, that a previous crisis of efficacy could lead to burnout instead of being a real component of the same (e.g., Salanova, Bresó, \& Schaufeli, 2005). On the other hand, another proposal is an "extended" engagement comprising the original dimensions and the efficacy subscale -stated positively- (Schaufeli \& Bakker, 2001; Schaufeli \& Salanova, 2007). In our study, efficacy beliefs, considered an independent resource, predicted engagement but not core burnout. Our results deserve further attention concerning the role and measurement of efficacy in the experience of engagement and burnout. 
A clear limitation of our design is its transversal nature since it does not allow for establishing any causal relationships between the analysed variables. Nevertheless, our data encourage exploring the hypothesis that the factors involved in student's welfare and academic success will coexist in a continuous transaction that researchers such as Bresó, Schaufeli, and Salanova (2011) have identified as positive and negative spirals. Thus, personal resources, such as intrinsic motivation, personal initiative or efficacy, would lead to implementing better coping strategies and the experience of positive emotions (Bandura 1997; Fredrickson, 2004), which, the latter, would reinforce the individual psychological resources (Pérez et al., 2018). On the contrary, low levels of personal resources would contribute to procrastination and maladaptive coping with academic demands (Salmela-Aro \& Read, 2017; O'Connor et al., 2016), followed by the experience of higher levels of stress (Bedewy \& Gabriel, 2015) and negative emotions (Aguayo-Muela \& Aguilar-Luzón, 2017), that would negatively affect personal resources.

Another limitation is that the age of our student sample was slightly higher than the average for first-year students, due to a few extreme values, although in our distribution $71.7 \%$ of the sample was between 17 and 21 years old. Additionally, a larger number of sample subjects would allow us a more precise analysis of the intervening variables.

The exclusive use of self-report measures is another limitation of the study, given the potential influence of the acquiescence bias on results. Besides, because participation in our study was voluntary, more likely that students were more motivated were eager to participate, whereas those who were less motivated were not. Nevertheless, our sample yielded a wide range of scores for the analysed variables.

Finally, given the relevance of the variables involved in engagement and burnout, and their role in the wellbeing and satisfaction of first-year students, some future studies and actions we propose include:

To expand in longitudinal studies and to test explanatory analysis models would allow for analysing the spirals models or virtuous and vicious circles to a greater extent, from a broader perspective.

To develop institutional actions to enhance students' engagement by promoting intrinsic motivation and efficacy beliefs, guiding them in their development of positive learning strategies, such as persistence, while simultaneously reducing the risk of students' burnout by orientating them to neither procrastinate nor avoid difficulties, and coping better with stress. The ultimate aim would be to increase students' psychological well-being and academic performance, reduce dropouts and improve retention (Seligman \& Adler, 2018), especially during their first academic year.

To focus primarily on the first academic year at the university as a critical period (Michavila et al., 2012; Tinto, 2006, 2012) during which initial expectations are confronted (Merhi, 2011), according to data on student dropout rates (e.g., Crue Universidades Españolas, 2018; European Commission, 2015).

To provide students proper orientation in an early stage (e.g., in secondary education) that encourages them to choose a degree from among those that motivate them more intrinsically (Garbanzo, 2007; Vizoso \& AriasGundín, 2016).

\section{References}

Aguayo-Muela, A. C. \& Aguilar-Luzón, M. C. (2017). Principales resultados de investigación sobre inteligencia emocional en docentes españoles [Main Results of Research on Emotional Intelligence in Spanish Teachers]. ReiDoCrea, 6, 170-193.

Bakker, A. B. \& Demerouti, E. (2013). The Job DemandsResources Model: State of the Art. Journal of Managerial Psychology, 22, 309-328. https://doi.org/10. 1108/02683940710733115

Bandura, A. (1997). Self-Efficacy: The Exercise of Control. New York, NY, US: Freeman/Times Books. 
Bandura, A. (2001). Social Cognitive Theory: An Agentic Perspective. Annual Review Psychology, 52, 1-26. https://doi.org/10.1146/annurev.psych.52.1.1

Barr, T., Sessa, V., Sumner, K., \& Bragger, J. (2015). Applying the Job Demands-Resources Model towards Understanding Student Stress. Computers in Human Behavior, 77(C), 317-325. https://doi.org/10.13140/ RG.2.1.4981.4885

Bedewy, D. \& Gabriel, A. (2015). Examining perceptions of academic stress and it sources among university students: The perception of Academic Stress Scale. Health Psychology Open, 1-9. https://doi.org/10. $1177 / 2055102915596714$

Bresó, E., Schaufeli, W. B., \& Salanova, M. (2011). Can a Self-Efficacy-Based Intervention Decrease Burnout, Increase Engagement, and Enhance Performance? A Quasi-experimental Study. Higher Education, 61, 339355. https://doi.org/10.1007/s10734-010-9334-6

Carmona-Halty, M., Salanova, S., Llorens, S., \& Schaufeli, W. (2018). How Psychological Capital Mediates between Study-related Positive Emotions and Academic Performance. Journal of Happiness Studies, 20(2), 605-617. https://doi.org/10.1007/s10902-0189963-5

Casuso, M. J. (2011). Estudio del estrés, Engagement y rendimiento académico en estudiantes universitarios de ciencias de la salud [Study of Stress, Engagement and Academic Performance in University Students of Health Sciences] (Doctoral thesis). Retrieved from https://riuma.uma.es/xmlui/bitstream/handle/10630/ 4926/TD\%20Maria\%20Jesus\%20Casuso\%20Holga do.pdf?sequence $=1$

Connor K. M. \& Davidson J. R. T. (2003). Development of a New Resilience Scale: The Connor-Davidson Resilience Scale (CD-RISC). Depression and Anxiety, 18, 76-82. https://10.1002/da.10113

Crue Universidades Españolas. (2018). La Universidad Española en Cifras 2016-17 [Spanish University in figures 2016-17]. Retrieved from
http://www.crue.org/Documentos\%20compartidos/Publicaciones/Universidad $\% 20$ Espa $\%$ C3\%B1 ola $\% 20$ en $\% 20$ cifras $/ 2018.1$ 2.12 -informe $\% 20 \mathrm{La} \% 20$ Universidad\%20Espa\%C3\%B1ola\%20en\%20Cifras.pdf

European Commission. (2015). Dropout and Completion in Higher Education in Europe. Luxembourg: Publications Office of the European Union https://doi.org/ $10.2766 / 826962$

Fredrickson, B. L. (2004). The Broaden-and-Build Theory of Positive Emotions. Philosophical Transactions of the Royal Society B: Biological Sciences, 359(1449), 1367-1378. https://doi.org/10.1098/rstb.2004.1512

Frese, M. \& Fray, D. (2001). Personal Initiative (PI): An Active Performance Concept for Work in the 21st Century. In B. M. Staw \& R. M. Sutton (Eds), Research in Organizational Behavior (vol. 23, pp. 133187). Amsterdam, NL: Elsevier.

Frese, M., Fray, D., Hilburger, T., Leng, K., \& Tag, A. (1997). The concept of personal initiative: Operationalization, reliability and validity in two German samples. Journal of Organizational and Occupational Psychology, 70, 139-161. https://doi.org/ 10.1111/j.2044-8325.1997.tb00639.x

Garbanzo, G. (2007). Factores asociados al rendimiento académico en estudiantes universitarios, una reflexión desde la calidad de la educación superior pública [Factors Associated with Academic Performance in University Students, a Consideration on the Public Higher Education Quality]. Revista Educación, 31, 43-63.

García-Ros, R., Pérez-González, F., Pérez-Blasco, J., \& Natividad, L. A. (2012). Evaluación del estrés académico en estudiantes de nueva incorporación a la universidad [Evaluation of Academic Stress in Fresh Students]. Revista Latinoamericana de Psicología, 44 (2), 143-154. https://doi.org/10.14349/ rlp.v44i2. 1038 
Goering, D., Shimazu, A., Zhou, F., Wadac, T., \& Sakai, R. (2017). Not if, but how they Differ: A Meta-analytic Test of the Nomological Networks of Burnout and Engagement. Burnout Research, 5, 21-34. https://doi.org/10.1016/j.burn.2017.05.003

González-Brignardello, M. P. \& Sánchez-ElviraPaniagua, A. (2013). ¿Puede amortiguar el engagement los efectos nocivos de la procrastinación académica? [Can Engagement Buffer the Harmful Effects of Academic Procrastination?]. Acción Psicológica, 10(1), 117-134. https://doi.org/10.5944 /ap.10.1.77039

Grant, L. \& Kinman G. (2012). Enhancing Well-being in Social Work Students: Building Resilience for the Next Generation. Social Work Education, 31(5), 605-621. https://doi.org/10.1080/02615479.2011.59 0931

Halbesleben, J. R. B. (2010). A Meta-analysis of Work Engagement: Relationships with Burnout, Demands, Resources, and Consequences. In A. B. Bakker \& M. P. Leiter (Eds.), Work Engagement: The essential in theory and research (pp. 102-117). New York, NY: Psychology Press.

Harvard, D. W. (Ed). (2016). Well-Being and Higher Education: A Strategy for Change and the Realisation of Education's Greater Purposes. Washington, DC: AAC\&U.

Kim, K. R. \& Seo, E. H. (2015). The Relationship between Procrastination and Academic Performance: A Metaanalysis. Personality and Individual Differences 82, 26-33 https://doi.org/10.1016/j.paid.2015.02.038

Klaassen, R. M., Krawchuk, L. L., \& Rajani, S. (2008). Academic procrastination of undergraduates: Low Self-efficacy to Self-regulate Predicts Higher Levels of Procrastination. Contemporary Educational Psychology, 33, 915-931, https://doi.org/10.1016/j. cedpsych.2007.07.001

Las-Hayas, A., Lisbona, A., \& Palací, F. (2018). Initiative in Work Teams: Adaptation and Validation of the
Personal Initiative at Group Level Scale. Revista de Psicología Social, 33(1), 1-32, https://doi.org/ 10.1080/02134748.2017.1385240

Lazarus, R. S. \& Folkman, S. (1987). Transactional Theory and Research on Emotions and Coping. European Journal of Personality, 1, 141-169. https://doi.org/ 10.1002/per.2410010304

Leiter, M. \& Maslach, C. (2017). Burnout and Engagement: Contributions to a New Vision. Burnout Research, 5, 55-57. https://doi.org/10.1016/j.burn.2017 .04 .003

Lisbona, A., Palací, F. J., Salanova, M., \& Frese, M. (2018). The Effects of Work Engagement and Selfefficacy on Personal Initiative and Performance. Psicothema, 30(1), 89-96. https://doi.org/10.7334/psicothema2016.245

Llorens, S., García-Renedo, M., \& Salanova, M. (2005). Burnout como consecuencia de una crisis de eficacia: un estudio longitudinal en profesores de secundaria [Burnout as a Consequence of a Crisis of Efficacy: A Longitudinal Study in Secondary School Teachers]. Revista de Psicología del Trabajo y de las Organizaciones, 21(1-2), 55-70.

Mäkikangas, A. (2016). Work Engagement-team Performance Relationship: Shared Job Crafting as a Moderator. Journal of Occupational and Organizational Psychology. https://doi.org/10.1111/joop.1215 4

Maricotui, L., Sulea, C., \& Lancu, M. (2017). Work Engagement or Burnout: Which Comes First? A Metaanalysis of Longitudinal Evidence. Burnout Research, 5(2), 35-43. https://doi.org/10.1016/j.burn. 2017.05.001

Martin, A. J. \& Marsh, H. W. (2006). Academic Resilience and its Psychological and Educational Correlates: A construct Validity Approach. Psychology in the Schools, 43, 267-282. https://doi.org/10.1002/ pits. 20149 
Martínez, I. \& Marques, A. (2005). Burnout en estudiantes universitarios de España y Portugal y su relación con variables académicas [Burnout in University Students from Spain and Portugal and their Relationship with Academic Variables]. Periódicos electrónicos en Psicología. Aletheia, 21, 21-30.

Martínez, I. \& Salanova M. (2003). Niveles de Burnout y Engagement en estudiantes universitarios. Relación con el desempeño y desarrollo profesional [Levels of Burnout and Engagement in university students. Relationship with professional development and performance]. Revista de Educación, 330, 361-384.

Martínez, I. M., Peñalver, J., \& Meneghel, I. (2016). Take Care of Well-Being: How Facilitators and Engagement Predict Performance of University Students. Multidisciplinary Journal for Education, Social and Technological Sciences, 3(1). https://doi.org/ 10.4995/muse.2016.3751

Maslach, C. \& Leiter, M. P. (1997). The truth about burnout: how organizations cause personal stress and what to do about it. San Francisco, United States of America: Jossey-Bass. https://doi.org/10.1002/job. 248

Merhi, R. (2011). Expectativas del estudiantado en la universidad del nuevo milenio [Expectations of Students in the New Millennium University]. La Cuestión Universitaria, 7, 23-31.

Michavila, F., García, J., Martínez, J., Merhi, R., Esteve, F., \& Martínez, A. (2012). Análisis de las políticas y estrategias de acogida e integración de los estudiantes de nuevo ingreso en las universidades españolas [Analysis of the Policies and Strategies of Reception and Integration of Freshmen Students in Spanish Universities]. Madrid, Spain: Cátedra UNESCO de Gestión y Política Universitaria.

Mokgele, K. R. F. \& Rothmann, S. (2014). A structural Model of Student Well-being. South African Journal of Psychology, 44(4), 514-527. https://doi.org/ $10.1177 / 0081246314541589$
Notario-Pacheco, B., Solera-Martínez, M., Serrano-Parra, M. D., Bartolomé-Gutiérrez, R., García-Campayo, J., \& Martínez-Vizcano, V. (2011). Reliability and Validity of the Spanish Version of the 10-item ConnorDavidson Resilience Scale (10-item CD-RISC) in young adults. Health Quality of Life Outcome, 5, 963. https://doi.org/10.1186/1477-7525-9-63

O'Connor, P., Nguyen, J., \& Anglim, J. (2016). Effectively Coping With Task Stress: A Study of the Validity of the Trait Emotional Intelligence Questionnaire-Short Form (TEIQue-SF), Journal of Personality Assessment, 3, 304-314. https://doi.org/10.1080/00223891. 2016.1226175

Pérez, M. C., Molero, M. M., Barragán, A. B., Martos, A., Simón, M. M., \& Gázquez, J. J. (2018). Autoeficacia y Engagement en estudiantes de Ciencias de la Salud y su relación con la autoestima [Self-efficacy and Engagement in Health Sciences students and their relationship with self-esteem]. Publicaciones, 48(1), 193-210. https://doi.org/10.30827/publicaciones. v48i1.7323

Ryan, R. \& Deci, E. (2000). Self-Determination Theory and the Facilitation of Intrinsic Motivation, Social Development, and Well-Being. The American Psychologist, 55(1), 68-78. https://10.1037/0003066X.55.1.68

Salanova, M. \& Llorens, S., (2016). Hacia una Psicología positiva aplicada [Towards an Applied Positive Psychology]. Papeles del Psicólogo, 3(37), 161-164.

Salanova, M., Bresó, E., \& Schaufeli, W. (2005). Hacia un modelo espiral de las creencias de eficacia en el estudio del Burnout y del Engagement [Towards a Spiral Model of Efficacy Beliefs in the Study of Burnout and Engagement]. Ansiedad y Estrés, 11, 215-231.

Salanova, M., Martínez, I., Bresó, E., Llorens, S., \& Grau, R. (2005). Bienestar psicológico en estudiantes universitarios: facilitadores y obstaculizadores del desempeño académico [Psychological Well-being in University Students: Facilitators and Obstacles for 
Academic Performance]. Anales de Psicología, 21(1), 170-180.

Salanova, M., Schaufeli, W. B., Llorens, S., Peiró, J. M., \& Grau, R. (2000). Desde el 'burnout'al 'engagement': ¿una nueva perspectiva? [From Burnout to Engagement: A New Perspective?] Revista de Psicología del Trabajo y las Organizaciones, 16, 117-134.

Salanova, M., Grau, R., Martínez, I. M., Cifre, E., Llorens, S., \& García-Renedo, M. (2004). Nuevos Horizontes en la investigación sobre Autoeficacia [New horizons in research on self-efficacy]. Castellón, Spain: Publicacions de la Universitat Jaume I.

Salmela-Aro, K. \& Read, S. (2017). Study Engagement and Burnout profiles among Finnish Higher Education Students. Burnout Research, 7, 21-28. https://doi.org/10.1016/j.burn.2017.11.001

Sánchez-Elvira-Paniagua, A., Fernández, E., \& Amor, P. (2006). Self-regulated Learning in Distance Education Students: Preliminary Data. In A. Delle Fave (Ed.), Dimensions of Wellbeing: Research and Intervention (pp. 294-314). Milan, Italia: FrancoAngeli

Sandín, B., Chorot, R, Lostao, L., Joiner, T. E., Santed, M. A., \& Valiente, R. M. (1999). Escalas PANAS de afecto positivo y negativo: Validación factorial $\mathrm{y}$ convergencia transcultural [PANAS Scales of Positive and Negative Affect: Factorial Validation and Cross-Cultural Convergence]. Psicothema, 11(1), $37-51$.

Schaufeli, W. B. \& Bakker, A. (2001). Work and Wellbeing: Towards a Positive Occupational Health Psychology. Gedrag y Organisatie, 14, 229-253.

Schaufeli, W. B. \& De Witte, H. (2017). Work Engagement in Contrast to Burnout: Real or Redundant? Burnout Research, 5, 1-2. https://doi.org/10.1016/ j.burn.2017.06.001

Schaufeli, W. B. \& Salanova, M. (2007). Efficacy or Inefficacy, that's the Question: Burnout and Engagement, and their Relationships with Efficacy Be- liefs. Anxiety, Stress and Coping, 20(2), 177-196. https://doi.org/10.1080/10615800701217878

Schaufeli W. B. \& Taris T. W. (2014). A Critical Review of the Job Demands-Resources Model: Implications for Improving Work and Health. In Bridging Occupational, Organizational and Public Health (pp. 4368). New York, NY, Springer. https://doi.org/10. 1007/978-94-007-5640-3_4

Schaufeli, W. B., Salanova, M., González-Romá, V., \& Bakker, A. B. (2002). The Measurement of Engagement and Burnout: A Confirmative Analytic Approach. Journal of Happiness Studies, 3, 71-92. https://doi.org/10.1023/A:1015630930326

Schaufeli, W. B., Martínez, I. M., Marqués-Pinto, A., Salanova, M., \& Bakker, A. (2002). Burnout and Engagement in University Students: A Cross-National Study. Journal of Cross-Cultural Studies, 33, 464481. https://doi.org/10.1177/0022022102033005003

Seligman, M. \& Adler, A. (2018). Positive Education. In J. F. Helliwell, R. Layard \& J. Sachs (Eds.), Global Happiness Policy Report: 2018 (pp. 52-73). New York, NY: Global Happiness Council.

Seligman, M. \& Csikszentmihalyi, M. (2001). Positive Psychology: An Introduction: Reply. American Psychologist, 56, 89-90. https://doi.org/10.1037/0003066X.56.1.89

Steel, P. (2007). The Nature of Procrastination: A Metaanalytic and Theoretical Review of Quintessential Self-regulatory Failure. Psychological Bulletin, 133, 65-94. https://doi.org/10.1037/0033-2909.133.1.65.

Steel, P. \& Klingsieck, K. B. (2016). Academic Procrastination: Psychological Antecedents Revisited. Australian Psychologist 51, 36-46. https://doi.org/10. 1111/ap.12173.

Taris, T. W., Ybema, J. F., \& Van Beek, I. (2017). Burnout and Engagement: Identical Twins or just Close Relatives? Burnout Research, 5, 3-11. https://doi.org/10. 1016/j.burn.2017.05.002 
Tinto, V. (2006). Research and Practice of Student Retention: What next? Journal of College Student Retention 2006, 8(1), 1-19.

Tinto, V. (2012). Completing College: Rethinking Institutional Action. Chicago, IL: The University of Chicago Press. https://doi.org/10.1086/676905

Vizoso, C. \& Arias-Gundín, O. (2016). Engagement, Burnout y rendimiento académico en estudiantes universitarios y su relación con la prioridad en la elección de la carrera [Academic Engagement, Burnout and Performance in University Students and their Relationship with Priority on Choosing the career]. Revista de Psicología y Educación, 11(1), 4560 .

Watson, D. \& Clark, L. A. (1988). Development and Validation of Brief Measures of Positive and Negative Affect: The PANAS Scales. Personality Social Psychology, 6, 1063-1070.

White, M., Slemp, G., \& Murray, S. (2017). Future Directions in Well-Being: Education, Organizations and Policy. New York, NY: Springer. https://doi.org/10. 1007/978-3-319-56889-8

Williams, N., Horrell, L., Edmiston, D., \& Brady, M. (2018). The Impact of Positive Psychology on Higher Education. The William \& Mary Educational Review, 5(1), 83-94.

You, J. W. (2016). The Relationship among College Students' Psychological Capital, Learning Empowerment, and Engagement. Learning and Individual Differences, 49, 17-24. https://doi.org/10.1016/j.lindif. 2016.05.001 
